\title{
MICROECONOMICS FOR MICROHOUSING IN INDIA - FORMAL HOUSING SOLUTIONS FOR THE URBAN POOR
}

\author{
Ananya Agarwal \\ The British School, New Delhi \\ DOI: 10.46609/IJSSER.2020.v05i07.016 URL: https://doi.org/10.46609/IJSSER.2020.v05i07.016
}

\begin{abstract}
As the issue of mass migration from rural to urban areas increases, so does the issue of overcrowding in cities, and an increase in informal settlements such as slums. To tackle this issue, the government has introduced schemes for microhousing to formalize housing solutions in unplanned settlements where the urban poor currently reside. Alongside microhousing, an industry for financing microhousing and providing loans also exists. However, structural issues with both government policy and participation of the private sector have led to a situation where there is still a lack of accessibility to formal housing solutions, and a lack of planned settlements at all. Therefore, this paper will examine the microeconomics of affordable micro housing in India and the issues that have arisen with respect to the same. The paper will argue that there needs to be a policy framework that goes beyond market solutions for any meaningful reform. The paper will suggest policy recommendations to address both the demand side and supply side problems in the micro housing market and draw from successful schemes and initiatives.
\end{abstract}

Keywords: Microeconomics, Microhousing, Housing solutions, Urban poor

\section{INTRODUCTION}

In the midst of ongoing housing crises in India, micro housing has taken off to be the new trend for affordable and formal housing solutions in metropolitan areas. The rural-urban migration and concentration of industry clusters around the peripheries of urban zones have led to increasing housing shortages — particularly for informal sector workers and households in the economically weaker sections (Gandhi, 2012; Kaushik, 2016). The market failures emanated from the lack of access to finance related to informal employment, limited savings, uncertain collateral, alternative types of property rights, incomplete housing finance markets, and the related lack of appropriate products (World Bank, 2019). 
International Journal of Social Science and Economic Research

ISSN: $2455-8834$

Volume: 05, Issue: 07 "July 2020"

As of data available in 2016, there was a shortage of 18 million homes across the country of which 15 million are needed for low income families earning less than 16,000 Indian Rupees (\$250) a month. As slums and unplanned real estate spring up, the housing shortfall is having significant repercussions on India's new city dwellers and the way its cities are developing (Kaushik, 2016). There are millions of low-income families who live in overcrowded, inadequate and unsafe spatchcock dwellings made with cheap and fragile material like rotting wood and plastic coverings, crammed between dusty paths and open sewers with virtually no sanitation, environmental risk factors and lack of even the barest infrastructure (Qazi, 2018). These are usually; socially homogenous encampments where the unskilled poor live among themselves, disconnected from others, making it harder for them to access the mainstream economy (Qazi, 2018).

Therefore, there is huge potential for formalizing these unplanned settlements and expanding micro housing. This paper will examine the micro economic theories surrounding micro housing and welfare schemes, and review the existing schemes available for micro housing loans and financing for the urban poor. The paper will then suggest policy recommendations for ways to solve the structural issues facing the market for micro housing, and accessibility to financing options.

\section{BACKGROUND}

At the national level, the government estimated a shortage of more than 18.78 million homes at the beginning of 2012, of which 95\% were in the EWS (Economically Weaker Sections) and LIG (Low Income Group) segments (Deloitte, 2016). Further, the country's total urban housing shortage is projected to be about 30 million by 2022. This ever increasing gap between demand and supply in the affordable housing segment is forcing people to live in slums and informal settlements (Deloitte, 2016). It is evident that the issue, if not dealt with effectively, can have tremendous negative impact on the country's economic growth and poverty reduction efforts (Deloitte, 2016).

The basic microeconomics of demand and supply affect the market for micro housing as well. On the supply side, there are simply not enough affordable housing options available and there is an inefficient redistribution of land and resources to accommodate the urban poor. On the supply side, lack of awareness on housing finance options and general lack of education and poverty affect the ability of the urban poor to buy housing, increasing informal and unplanned settlements. Ever since the first National Housing Policy in 1988, the government has tried to reform the housing and real estate sector yet many affordable housing schemes have underachieved (Kaushik, 2016). 


\section{International Journal of Social Science and Economic Research}

ISSN: $2455-8834$

Volume: 05, Issue: 07 "July 2020"

The structural issues on the demand and supply side have led to a situation of market failure, and an inefficient allocation of resources intended for the urban poor. House prices have been stretching further and further away from normal wages, making it difficult for low-income families to get on the housing ladder (Qazi, 2018). Faced with the enormity of the housing need and financial weakness of those in need, the government builds low-income housing units and distributes them at very high levels of subsidy (Qazi, 2018).

It is important to change our very notion of demand from the urban poor in order to make any meaningful policy changes. It is not merely an economics of purchase, but an economics of aesthetics. People actually do not demand houses; they demand habitats. A house is an object; a habitat is a node in an ecosystem of overlapping networks - physical (roads, water, power and sanitation), economic (labour markets, urban transport, distribution and retail, entertainment) and social (education, health, security, family and friends) (Qazi, 2018). The ability to connect to all of these networks makes a habitat valuable. Understanding this has implications for programs like slum re-development (Qazi, 2018).

It is key to realize that market solutions are not enough to tackle the issue. There has to be adequate amount of public housing as well, which means housing stock created by public bodies and public agencies and similar other bodies at city or state or other such levels (Kaushik, 2016; Gandhi, 2012). Innovative thinking is needed to address the challenges facing India's low income workers (Kaushik, 2016). As the supply side of India's housing market is currently skewed toward middle income to upper middle income group, low income workers are particularly vulnerable (Kaushik, 2016). Many do not earn a regular salary. Therefore, there need to be reforms in the space of loans provided to workers in the informal sector for micro housing.

\section{DISCUSSION}

There are several existing schemes for micro-housing and related loans, and some examples are as follows. For example, the The Pradhan Mantri Awas Yojana (PMAY) was launched in June 2015 to build 20 million houses for the urban poor (Deloitte, 2016). In order to address the shortfall, the scheme envisages to tackle the issues through four models: In situ Slum Redevelopment, Affordable Housing in Partnership and Subsidy for beneficiary-led individual house construction and Credit linked subsidy (Deloitte, 2016). In addition, it has suggested policy reforms to implementing agencies. The government has attempted to open up of Foreign Direct Investment (FDI) for development of townships, housing, built-up infrastructure and construction-development (Deloitte, 2016). However, not much traction has been seen in the Affordable Housing segment till date (Deloitte, 2016). 


\section{International Journal of Social Science and Economic Research}

ISSN: $2455-8834$

Volume: 05, Issue: 07 "July 2020"

According to data from the National Housing Bank (NHB), there are about 100 housing finance companies (HFCs) operating in India currently (Acharya, 2019). Within the past two to three years, close to 15-20 companies have come up with a focus on lending to the informal sector, where borrowers typically don't possess the requisite documents to avail of loans from banks or bigger financial institutions (Acharya, 2019). There has been a particularly steep growth in micro housing loans, giving loans to people engaged in informal sector, and who do not possess adequate documents to avail loan from banks (Acharya, 2019). A typical borrower could be an artisan, driver, domestic help or daily wage-earner. What differentiates the loan from normal housing loan is the monthly repayment cycle, along with tight monitoring of the portfolio through personal contact -- a model similar to microfinance (Acharya, 2019). However, unlike the microfinance model, the loan in the micro housing sector is generally granted with collateral. The interest rates charged in the loans are about 5-6 per cent higher than the prevailing market rates (Acharya, 2019).

The Low Income Housing Project carried out by the World Bank between May 2013 and March 2018 is a good example to demonstrate the effectiveness of micro housing loans in fostering formal housing, and barriers to its implementation. The project aimed to provide access to sustainable housing finance for low-income households to purchase, build, or upgrade their dwellings (World Bank, 2019). It addressed the challenge of access to finance for urban housing emanating from the "informal" nature of low-income households. This informality occurs because both undocumented incomes and the nature of property rights constrain the use of property as financing collateral (World Bank, 2019). To date, the project has reached more than 15,000 low-income households across 17 states in India through 17 primary lending institutions, including lenders serving households headed by women (World Bank, 2019). These informal sector beneficiaries were able to access formal housing finance loans at fully market-based rates (World Bank, 2019).

While targeted borrowers under the project could have both formal and informal sources of income as well as collateral /primary security, the objective was to test sustainable lending models for informal segments given market failures in access to formal channels for these segments (World Bank, 2019). The project supported upgrading the quality of affordable housing by applying safeguard measures, which helps improve human development outcomes (World Bank, 2019).

The project provided strong evidence that income informality tends to constrain access to formal finance more than affordability and that with the right product design, flexibility, and risk mitigation practices, these constraints can be meaningfully addressed (World Bank, 2019). For example, the LIHF has supported innovations in underwriting and monitoring methods drawing 


\section{International Journal of Social Science and Economic Research}

ISSN: $2455-8834$

Volume: 05, Issue: 07 "July 2020"

on data analytics, expert systems, and use of alternate metrics (as compared to traditional predictors of default behavior that would have constrained financing for informal households) (World Bank, 2019). This successful innovation has given retail lenders much more confidence to finance housing against informal incomes, and these lenders have continued offering their products to informal beneficiaries even outside the scope of the World Bank loan (World Bank, 2019).

The challenges facing housing microfinance programmes include affordability constraints, especially for rural households; high land prices in the case of urban clients; commercial viability of the microfinance lenders; and need for new products, including savings-for-housing instruments, and for mechanisms limiting disaster and disability/death risk in housing lending (Qazi, 2018). Careful blending of government policies, public-private partnerships, smart subsidies, planning and technical assistance for housing microlending would be required to further develop the low-income housing and housing finance markets (Qazi, 2018). Therefore, following a model similar to the Low Income Housing Project of the World Bank would be effective in creating a sustainable model at fully market based rates.

\section{CONCLUSION}

From the above analysis, it is clear that there exist structural issues both on the demand side and supply side. Only when both are addressed, can market solutions coupled with welfare schemes make a meaningful change in the market for affordable housing and housing finance.

On the supply side, there is benefit for India to look to other countries facing the issue of mass migration, and borrowing from successfully implemented policies. Countries like China have successfully implemented mass housing plans. For example, Shanghai has adopted four approaches to affordable housing for different types of residents — low rent housing, a public rental housing system, houses on shared ownership, and houses for people relocated from old dilapidated buildings (Kaushik, 2016). Indonesia pursues a National Housing Policy that involves cross subsidies that actively encourage private firms to build a set number of low cost houses for every luxury home they build (Kaushik, 2016). Therefore, public private partnerships could help with the supply side issue of the lack of affordable housing and the efficient allocation of land and resources to address scarcity of resources.

On the demand side, it is key for there to be policies and schemes to improve access to microhousing loans and an improvement in methods of raising outreach and awareness about the same. A new stream of lending has emerged, called housing microfinance. It draws on proven best practices in microfinance but adapted to the classical housing finance paradigm. This has been highly successful wherever governments are offering long-term tenancies and shared-ownership 
International Journal of Social Science and Economic Research

ISSN: $2455-8834$

Volume: 05, Issue: 07 "July 2020"

housing in a supportive context (Qazi, 2018; Gandhi, 2012). But the sector is still in need of a more sustainable business model to grow (Qazi, 2018; Gandhi, 2012).

Endowing slum dwellers with mortgageable titles can open the gates to numerous opportunities for improving health, education, employment and providing entitlements to social programmes (Qazi, 2018; Deloitte, 2016). While formal land titles are not necessary for housing microfinance, land security is essential. There is a need for policy reforms to stimulate private sector participation through creative partnerships and fruitful linkages for fostering a sound ecosystem for affordable housing (Qazi, 2018). Given that legal status is a strong marker of deprivation, government schemes should target adequate resources to non-notified slums. The lack of defensible and documented rights (for example, property registration documents) denies slum dwellers benefits of the agglomeration economies that would boost their productivity (Qazi, 2018). Therefore, they prefer to choose older homes in established neighbourhoods.

As the issue is exacerbated over the next decades, the government must begin contemplating and putting into motion long term solutions now. Importantly, it is crucial for the debate and policy on the issue to move beyond one of economics, but also acknowledge that it is a human rights issue, as the urban poor have a right to live with dignity. It should not be acceptable to have large sectors of the population experiencing exclusion, evictions, discrimination, insecure tenure, and lack of hope of accessing adequate and affordable housing in their lifetimes (Qazi, 2018; Kaushik, 2016).

\section{REFERENCES}

Acharya, N., (June 10 2019), 'Micro housing finance companies choke on acute fund crunch post DHFL crisis', Business Standard

Deloitte, (August 2016), 'Mainstream Affordable Housing in India', Working Paper

Gandhi, S., (March 2012), 'Economics of Affordable Housing in Indian Cities The Case of Mumbai', Environment and Urbanization ASIA, 3(1)

Kaushik, P., (May 2016), 'How to tackle India's affordable housing challenge', World Economic Forum

Qazi, M., (Oct 12 2018), 'Can Microhousing deliver on its promise?', The Asian Age

World Bank, (April 2 2019), ‘Affordable Housing for India’s Urban Poor’, World Bank Results Briefs 